\title{
UPAYA MENINGKATKAN KEMANDIRIAN ANAK MELALUI POLA ASUH DEMOKRATIS
}

\author{
Roudlotun Ni'mah \\ roudlotun7@gmail.com \\ UNU Sunan Giri Bojonegoro \\ Zahrotun Nikmah \\ zahrotunnimah6@gmail.com \\ UNU Sunan Giri Bojonegoro
}

\begin{abstract}
Independence is very important in a person's life, because with independence children can become more responsible in meeting their needs and fostering confidence in children. A child who has a sense of independence will be able to adjust to the environment and the circumstances of the child's own environment and be able to overcome the difficulties that occur. Children's independence is communicative during development, where individuals will continue to learn to be independent in facing environmental situations, so as to be able to think and act alone with their independence. This type of research is qualitative research, which is research in the form of words, not in the form of numbers. Qualitative research is obtained through a wide variety of data collection techniques such as interviews, document analysis, focused discussions, or observations that have been outlined in field records (transkip). Another form of research cauldron This research was conducted the SDN TAPELAN Institution precisely located in Tapelan Village, Bojonegoro Regency Cotton District. The results of this study, that efforts of independence by democratic parenting methods accustom children to eat alone, by means of democratic parenting tells children to eat patiently. Democratic parenting sets an example and tells children to wear their own clothes in a democratic parenting way. Democratic parenting the way parents provide motivation or encouragement to children that children are able to do things independently by means of democratic parenting
\end{abstract}

Keywords:. Independence children, democratic parenting

\begin{abstract}
Abstrak: Kemandirian sangat penting dalam kehidupan seseorang, karena dengan kemandirian anak bisa menjadi lebih bertanggung jawab dalam memenuhi kebutuhannya serta menumbuhkan rasa percaya diri pada anak. Seorang anak yang memiliki rasa kemandirian akan mampu menyesuaikan diri dengan lingkungan serta keadaan lingkungan anak itu sendiri dan dapat mengatasi kesulitan yang terjadi. Kemandirian anak bersifat komulatif selama perkembangan, dimana individu terus akan belajar untuk bersikap mandiri dalam menghadapi situasi lingkungan, sehingga mampu berfikir dan bertindak sendiri dengan kemandiriannya. Jenis penelitian ini adalah penelitian kualitatif, yaitu penelitian yang berbentuk kata - kata, bukan dalam bentuk angka. Penelitian kualitatif diperoleh melalui berbagai macam teknik pengumpulan data misalnya wawancara, analisis dokumen, diskusi terfokus, atau observasi yang telah dituangkan dalam catatan lapangan ( transkip ). Bentuk lain penelitian kualitat Penelitian ini dilakukan di Lembaga SDN TAPELAN tepatnya berada di Desa Tapelan Kecamatan Kapas Kabupaten Bojonegoro. Hasil penelitian ini, Bahwa Upaya kemandirian dengan cara pola asuh Demokratis membiasakan anak untuk makan sendiri, dengan cara pola asuh demokratis menyuruh anak makan dengan sabar. Pola asuh Demokratis memberikan contoh dan menyuruh anak untuk memakai baju sendiri dengan cara pola asuh demokratis. Pola asuh demokratis cara orang tua memberikan motivasi atau dorongan kepada anak bahwa anak mampu mengerjakan sesuatu dengan mandiri dengan cara pola asuh demokratis.
\end{abstract}

Kata Kunci: kemandirian anak, pola asuh demokratis 


\section{Pendahuluan}

Dalam proses pendidikan di era digital ini, peran orang tua harus mencermati cara-cara mengetahui kemampuan anak untuk menyikapi dan memandang dirinya secara positif agar menggunakan perangkat digital dengan baik. Melihat dari perkembangan teknologi seakarang ini, penggunaan perangkat digital bagi kehidupan anak telah berpengaruh terhadap kehidupan anak. ${ }^{1}$ Maka Pengawasan terhadap anak sangat penting untuk diwujudkan karena banyak informasi yang masuk dan anak harus bisa memilih informasi yang cocok dan sesuai tahap perkembangannya.

Menurut Undang-Undang Republik Indonesia No 20 Tahun 2003 pasal 1 ayat 14 yang menyebutkan bahwa, pendidikan anak usia dini adalah suatu upaya pembinaan yang ditujukan kepada anak sejak lahir sampai usia enam tahun yang dilakukan melalui pemberian rangsangan pendidikan untuk membantu pertumbuhan, perkembangan fisik dan psikis anak agar anak memiliki kesiapan untuk memasuki pendidikan yang lebih lanjut. ${ }^{2}$

Mendidik anak-anak menjadi manusia yang taat beragama Islam ini, pada hakekatnya adalah untuk melestarikan fitrah yang ada dalam setiap diri pribadi manusia, yaitu beragama tauhid, agama Islam. Seorang anak itu mempunyai "dwi potensi" yaitu bisa menjadi baik dan buruk, oleh karena itu orang tua wajib membimbing, membina dan mendidik anaknya berdasarkan petunjuk-petunjuk dari Allah dalam agama-Nya, agama Islam agar anak- anaknya dapat berhubungan dengan beribadah kepada Allah dengan baik dan benar. Maka anak harus mendapat asuhan, bimbingan dan pendidikan yang baik dan benar agar dapat menjadi remaja, manusia dewasa dan orang tua yang beragama dan selalu hidup agamis. Sehingga dengan demikian anak sebagai penerus generasi dan cita-cita orang tuanya dapat tumbuh dan berkembang menjadi manusia yang dapat memenuhi harapan orang tuanya dan sesuai dengan kehendak Allah. ${ }^{3}$

Kehidupan yang tenteram, bahagia dan harmonis baik bagi orang yang beriman maupun orang kafir, merupakan suatu kebutuhan mutlak. Setiap orang yang menginjakkan kakinya dalam berumah tangga pasti dituntut untuk dapat menjalankan bahtera keluarga itu dengan baik. Kehidupan keluarga sebagaimana diungkap di atas, merupakan masalah besar yang tidak bisa dianggap sepele dalam mewujudkannya. Apabila orang tua gagal dalam memerankan dan memfungsikan peran dalam membina hubungan masing- masing pihak maupun dalam memelihara, mengasuh dan mendidik anak yang semula jadi dambaan keluarga, perhiasan dunia, akan terbalik menjadi bumerang dalam keluarga, fitnah dan siksaan dari Allah.

Kaitannya dengan pemeliharaan dan pengasuhan anak ini, ajaran Islam yang tertulis dalam Al-Qur'an, Hadits maupun hasil ijtihad para ulama (intelektual Islam) telah menjelaskannya secara rinci, baik mengenai pola pengasuhan anak, maupun pasca kelahirannya. Allah SWT memandang bahwa anak merupakan perhiasan dunia. Anak didik yang ada pada jalur SEKOLAH DASAR/ MADRASAH IBTIDAIYYAH ini biasanya berada pada rentang usia nol sampai enam tahun, dimana perkembangan kecerdasan anak sedang berada pada masa emas atau sering di sebut dengan usia emas (golden age). Hal ini menunjukkan pentingnya upaya untuk mengembangkan seluruh potensi yang di miliki anak. Pada masa ini fisik dan psikis siap menerima respon stimulasi yang di berikan oleh lingkungan. Masa ini merupakan masa yang tepat untuk meletakkan dasar pertama bagi pengembangan kemampuan fisik, kognitif, bahasa, sosial emosional, konsep diri, disiplin, seni moral dan nilai-nilai agama. Oleh sebab itu, di butuhkan kondisi dan stimulasi yang sesuai dengan kebutuhan anak, agar pertumbuhan dan perkembangan anak tercapai secara optimal.

\footnotetext{
${ }^{1}$ Herimanto dan Winarno, ilmu sosial \& budaya dasar, (Cet. VI; Jakarta: PT Bumi Aksara, 2012), hlm. 161

${ }^{2}$ Novan Ardy Wiyani, M.Pd.I. Konsep Dasar SEKOLAH DASAR/ MADRASAH IBTIDAIYYAH, (Yogyakarta: Gava Media, 2016), hlm. 01.

${ }^{3}$ Bakir Yusuf Barmawi, Pembinaan Kehidupan Beragama Islam Pada Anak, (Semarang: Dina Utama, 1993), hlm. 5.
} 
Salah satu lembaga pendidikan yang menstimulasi perkembangan dan pertumbuhan anak adalah SDN TAPELAN, merupakan sebuah lembaga pendidikan anak usia dini yang berada di bawah naungan Dinas Pendidikan Kabupaten Bojonegoro, sebagai lembaga pendidikan anak usia dini yang berbasis sosial ekonomi menengah ke bawah. Dalam proses perkembangan dan pertumbuhan anak, tentunya menimbulkan beragam persoalan yang dihadapi. Dan hasil observasi peneliti pada SDN TAPELAN di dapati berbagai permasalahan antara lain : (1) kurangnya kemandirian siswa (2) ketergantungan terhadap orang tua (3) ketidak tegaan orang tua meninggalkan anaknya belajar di kelas (4) serta masih kurangnya kepercayaan siswa terhadap guru, sehingga siswa masih gampang menangis dan kurang mandiri. ${ }^{4}$

Kemandirian sangat penting dalam kehidupan seseorang, karena dengan kemandirian anak bisa menjadi lebih bertanggung jawab dalam memenuhi kebutuhannya serta menumbuhkan rasa percaya diri pada anak. Seorang anak yang memiliki rasa kemandirian akan mampu menyesuaikan diri dengan lingkungan serta keadaan lingkungan anak itu sendiri dan dapat mengatasi kesulitan yang terjadi. Kemandirian anak bersifat komulatif selama perkembangan, dimana individu terus akan belajar untuk bersikap mandiri dalam menghadapi situasi lingkungan, sehingga mampu berfikir dan bertindak sendiri dengan kemandiriannya (Tjandradingtyas). ${ }^{5}$

Pentingnya kemandirian bagi usia dini dinyatakan oleh Anita Lie dan Sarah Prasasti yaitu agar anak bisa menjalani kehidupan tanpa ketergantungan kepada orang lain. Kriteria anak yang sudah mencapai kemandirian, menurut Steinberg (Mustika Dewanggi dkk.) yaitu apabila anak mampu menjalankan atau melakukan sendiri aktivitas hidup terlepas dari pengaruh kontrol orang lain terutama orangtua. Novan Ardy Wiyani menambahkan karakter mandiri yang dimiliki anak akan sangat bermanfaat bagi anak dalam melakukan prosedur keterampilan dan bergaul dengan orang lain. Proses pembentukan kemandirian anak membutuhkan dorongan dan dukungan dari lingkungan terkecil anak, yaitu keluarga terutama orangtua dan guru sekolah dasar/ madrasah ibtidaiyyah. Novan Ardy Wiyani menjabarkan peran orangtua dan guru sekolah dasar/ madrasah ibtidaiyyah dalam membentuk kemandirian anak yaitu memberikan pemahaman positif pada diri anak, mendidik anak terbiasa hidup rapi (menyiapkan tempat penyimpanan mainan, memberikan contoh, membuat kalender, dan mengajarkan konsekuensi hidup tidak rapi), memberikan permainan yang dapat membentuk kemandirian anak (permainan outdoor dan game komputer), memberikan pilihan sesuai dengan minat anak, membiasakan anak berperilaku sesuai dengan tata krama, dan memotivasi anak supaya tidak malas-malasan. ${ }^{6}$

Adapun faktor-faktor yang berpengaruh terhadap tingkat kemandirian anak usia prasekolah terbagi menjadi dua, meliputi faktor internal dan faktor eksternal. Faktor internal merupakan faktor yang ada dari diri anak itu sendiri yang meliputi emosi dan intelektual. Faktor emosi ini ditunjukkan dengan kemampuan mengontrol emosi dan tidak terganggunya kebutuhan emosi orang tua. Sedangkan faktor intelektual diperlihatkan dengan kemampuan untuk mengatasi berbagai masalah yang dihadapi. Sementara itu faktor eksternal yaiti faktor yang datang atau ada di luar anak itu sendiri. Faktor ini meliputi lingkungan, karakterustik, sosial, stimulasi, pola asuh, cinta dan kasih

\footnotetext{
${ }^{4}$ Penelitian di Lembaga SDN Tapelanjam 08.00 pagi, 5 Maret 2018.

${ }^{5}$ Agus Wibowo, pendidikan Karakter Anak Usia Dini, Pustaka Belajar, 2013, hlm. 30.

${ }^{6}$ Novan Ardy Wiyani. Bina Karakter Anak Usia Dini: Panduan Orangtua dan Guru dalam membentuk Kemandirian dan Kedisiplinan Anak Usia Dini,(Yogyakarta: Ar-Ruzz Media, 2012), hlm. 50.
} 
sayang, kualitas informasi anak dan orang tua, pendidikan orang tua dan status pekerjaan ibu (Soetijiningsih).?

Kemandirian anak dipengaruhi oleh berbagai faktor, salah satunya faktor lingkungan yaitu keluarga terutama orangtua. Benner dan Fox (Rita Eka Izzaty) mengungkap intisari dari teori ekologis Bronfenbrenner mengenai perkembangan anak yang menyatakan bahwa keluarga merupakan bagian dari lapisan mikrosistem yaitu sebagai lingkungan yang paling berpengaruh pada perkembangan anak. Keluarga, khususnya orangtua yang berpengaruh pada perkembangan anak salah satunya peran penting orangtua dalam kemandirian anak. Hal ini ditegaskan oleh Novan Ardy Wiyani bahwa orangtua memiliki peran nyata dalam pembentukan karakter mandiri anak, sehingga Novan Ardy Wiyani menyatakan dengan pemberian stimulasi yang teratur dan terarah di lingkungan keluarga, anak akan lebih cepat mandiri. ${ }^{8}$

Keluarga secara sederhana dapat diartikan sebagai suatu lingkungan yang di dalamnya terdapat sekelompok orang yang terdiri dari orang tua dan anak. Pada lingkungan keluarga inilah anak usia dini mendapatkan pendidikan pertama dari orang tuanya. Secara umum keluarga dapat digolongkan menjadi tiga jenis yaitu keluarga inti, keluarga konjugal dan keluarga luas. (1) keluarga inti merupakan jenis keluarga yang paling dasar sekaligus paling kecil cakupannya. Keluarga inti merupakan jenis keluarga yang memegang peranan terbesar dalam kehidupan setiap orang. Keluarga inti terdiri atas ayah, ibu dan anak. (2) keluarga konjugal merupakan keluarga yang terdiri dari ayah, ibu, anak yang dilengkapi dengan keberadaan / interaksi dari orang tua ayah ataupun ibu ( kakek nenek ). (3) keluarga luas merupakan jenis keluarga dengan jumlah dan juga cakupan yang paling besar.?

Adapun keluarga merupakan lingkungan sosial pertama yang ditemui anak ketika anak diizinkan untuk melihat dan menikmati dunia. Pertemuan dengan ibu, ayah dan lingkungan dalam keluarga itu sendiri menjadi subjek sosial yang nantinya akan membentuk dasar anak dengan orang lain. Hubungan anak dengan orang tua dan anggota keluarga lainnya dapat dianggap sebagai suatu sistem yang saling berinteraksi. Sistem-sistem tersebut berpengaruh pada anak baik secara langsung maupun tidak, melalui sikap dan cara pengasuhan anak oleh orang tua. ${ }^{10}$

Pola asuh adalah merupakan suatu cara terbaik yang dapat ditempuh orang tua dalam mendidik anak-anaknya sebagai perwujudan dari rasa tanggung jawab kepada anak-anaknya. Pola asuh yang dilakukan orang tua sama dengan bagaimana seorang pemimpin suatu individu maupun kelompok, karena pada dasarnya orang tua juga bisa disebut sebagai pemimpin sebagaimana definisi kepemimpinan yakni : leadership is the art of coordinating and motivating individuals and group to achieve the desired end. Dalam arti bahwa seorang pemimpin atau sebagai orang dalam membimbing anakanaknya harus menggunakan seni dalam mengorganisasikan pola asuh dan dalam memotivasi anakanaknya dalam keluarga untuk mencapai tujuan akhir sesuai dengan tujuan pendidikan islam itu sendiri yakni mencapai manusia insan kamil. ${ }^{11}$

\footnotetext{
${ }^{7}$ Novan Ardy Wiyani. Bina Karakter Anak Usia Dini: Panduan Orangtua dan Guru dalam membentuk Kemandirian dan Kedisiplinan Anak Usia Dini,hlm. 52.

${ }^{8}$ Novan Ardy Wiyani. Bina Karakter Anak Usia Dini: Panduan Orangtua dan Guru dalam membentuk Kemandirian dan Kedisiplinan Anak Usia Dini,hlm. 53.

${ }^{9}$ Novan Ardy Wiyani, M.Pd.I. Konsep Dasar SEKOLAH DASAR/ MADRASAH IBTIDAIYYAH, (Yogyakarta: Gava Media, 2016), hlm. 183.

${ }^{10}$ M. Shocib. Pola Asub Orangtua. Jakarta: Rineka cipta.1998, hlm. 57.

${ }^{11}$ Dr. Mansur, M.A. Pendidikan Anak Usia Dini dalam Islam, Jakarta: Pustaka Belajar. 2005, hlm. 350.
} 
Kingsley Price berpendapat bahwa the formation of the child's character is varacity. Setiap orang tua mengharapkan anak-anaknya menjadi anak yang sholeh dan berperilaku yang baik (ihsan). Oleh karena itu dalam membentuk karakter anak harus secermat dan seteliti mungkin. ${ }^{12}$

Pola asuh orang tua merupakan interaksi antara anak dan orang tua selama melibatkan kegiatan pengasuhan. Pengasuhan ini berarti orang tua mendidik, membimbing dan mendisiplinkan serta melindungi anak untuk mencapai kedewasaan sesuai dengan norma-norma yang ada dalam masyarakat (Habib). Terdapat tiga kecenderungan dalam pola pengasuhan yang otoriter, demokratis dan permisif (Hurlock). ${ }^{13}$

Dalam kehidupan sehari-hari, anak hidup dalam lingkungan, masyarakat dan budaya yang terus-menerus mempengaruhi perkembangan dan tingkat kemandiriannya. Pola asuh orang tua mempunyai peranan yang sangat penting dalam kehidupan anak. Melalui orang tua, anak beradaptasi dengan lingkungannya dan mengenal dunia sekitarnya serta pola pergaulan hidup yang berlaku di lingkungannya. Ini disebabkan oleh orang tua merupakan dasar pertama bagi pembentukan pribadi anak. Orang tua memegang peranan utama dan pertama bagi pendidikan anak. Mengasuh, membesarkan dan mendidik anak merupakan tugas mulia yang tidak lepas dari berbagai halangan dan tantangan.

Pola pengasuhan orang tua yang sangat beragam antara orang tua satu dengan orang tua lain sangat berbeda, sehingga menjadikan kemandirian anak yang satu dengan yang lain tentunya juga akan berbeda. Menurut Hasan tipe pola asuh ada tiga yaitu tipe pola asuh authoritatif atau demokratis, tipe pola asuh otoriter, tipe penyabar dan tipe penelantar. ${ }^{14}$

Adapun faktor pendorong orang tua terhadap pendidikan anak usia dini adalah : (1) Faktor Pendidikan, adapun tingkat pendidikan seseorang akan mempengaruhi segala sikap dan tindakannya. Demikian juga sebagai orang tua dalam melaksanakan berbagai upaya baik spritual (psikis) ataupun fisik juga akan sangat di pengaruhi oleh tingkatan pendidikannya. (2) Faktor Keagamaan, orang tua yang mempunyai dasar agama yang kuat, akan kaya berbagai cara untuk melaksanakan upaya baik psikis maupun fisik terhadap anaknya. (3) Faktor Lingkungan, lingkungan juga merupakan faktor sangat kuat yang dapat memepengaruhi upaya orang tua secara psikis dan fisik terhadap anak usia dini.

\section{Kajian Teori}

\section{Pola Asuh Demokratis}

Menurut Gunarsa "pola asuh orang tua adalah cara terbaik yang dapat di tempuh orang tua dalam mendidik anak sebagai perwujudan dari rasa tanggung jawab kepada anak". Menurut Hasan secara terminologi pengasuhan berasal dari kata "asuh" yang artinya pemimpin, pengelola, pembimbing, sehingga "pengasuh" adalah orang yang melaksanakan tugas membimbing, memimpin, mengelola". ${ }^{15}$

Baumerind dalam Santrock "mengemukakan bahwa pola asuh orang tua adalah cara terbaik orang tua dalam mendidik anak sebagai perwujudan dari rasa tanggung jawab kepada anak". Tarsis

\footnotetext{
${ }^{12}$ Dr. Mansur, M.A.Pendidikan Anak Usia Dini dalam Islam,hlm. 351.

${ }^{13}$ Santrock.J.W. Perkembangan Anak. Jakarta. Penertbit Erlangga. 2007, hlm .40.

14 Agus Wibowo, pendidikan Karakter Anak Usia Dini, Pustaka Belajar, 2013,hlm. 72.

${ }^{15}$ Ummi Nurul Hikmah," Pengaruh Pola Asuh Orang Tua Terhadap kemandirian Anak Usia Dini,'(Skripsi S1 Fakultas

Keguruan dan Ilmu Pendidikan Universitas Muhammadiyah Sukarta 2012), hlm. 5-6.
} 
Tarmudji mengungkapkan bahwa pola asuh orang tua merupakan interaksi antara anak dan orang tua selama mengadakan kegiatan pengasuhan. Menurut kamus besar Bahasa Indonesia bahwa "pola adalah model, sistem atau cara kerja", Asuh adalah "menjaga, merawat, mendidik, membimbing, membantu, malatih dan sebagainya. ${ }^{16}$

Menurut Santrock pengasuhan demokratis dimana orang tua lebih mendukung anak agar bersikap mandiri namun orang tua tetap membatasi dan memegang kendali apa yang dilakukan anak. Orang tua dengan gaya pengasuhan ini memberikan kesempatan kepada anak-anaknya untuk berkomunikasi, orang tua juga bersikap hangat dan mengasuh pada anaknya.

Pengasuhan orang tua yang demokratis akan menjadikan perilaku anak yang kompeten secara sosial. Anak dengan pola asuh demokratis biasanya mampu mandiri dan memiliki tanggung jawab sosial. Pada pola asuh ini Muallifah menjelaskan hak dan kewajiban antara anak dan orang tua diberikan secara adil dan saling melengkapi satu sama lain, orang tua melibatkan anak dalam mengambil keputusan yang terkait dengan kepentingan keluarga, mengendalikan dan mewajibkan anak-anaknya bertindak dengan berpikir sesuai usia dan kemampuan mereka, namun orang tua tetap memberikan kehangatan, bimbingan dan komunikasi dua arah.

Orang tua memberikan penjelasan dan alasan atas hukuman dan larangan yang diberikan kepada anak, orang tua selalu mendukung apa yang dilakukan oleh anak tanpa membatasi segala potensi yang dimilikinya serta kreativitasnya namun tetap membimbing anak- anaknya. Dalam bertindak kepada anak, orang tua selalu memberikan alasan kepada anak, orang tua juga cenderung tegas, tetapi kreatif dan percaya diri, mandiri, bahagia, serta memiliki tanggung jawab sosial.

Anak dari orang tua seperti ini akan tumbuh menjadi anak yang mandiri, tegas terhadap diri sendiri, ramah dengan teman sebaya, dan mau bekerja sama dengan orang tua. Kemungkinan mereka akan berhasil secara intelektual dan sosial, menikmati kehidupan, dan memiliki motivasi yang kuat untuk maju menjadi lebih baik (Muallifah). ${ }^{17}$ Adapun indikator-indikator pola asuh demokratis diantaranya adalah sebagai berikut : (1) kedisiplinan (2) kebersamaan (3) kegotong royongan. ${ }^{18}$

Setiap orang mempunyai sejarahnya sendiri-sendiri dan latar belakang yang sering kali sangat jauh berbeda. Entah itu latar belakang keluarga, lingkungan tempat tinggal atau pengalaman pribadinya. Perbedaan ini sangat memungkinkan pola asuh yang berbeda terhadap anak. Baumrind, menjelaskan faktor-faktor yang mempengaruhi pola asuh demokratis anak antara lain : 1). Pengaruh keluarga asal : Faktor yang penting yang kelak mempengaruhi kualitas perkawinan seseorang, menentukan pilihan pasangannya, mempengaruhi pola interaksi komunikasi antara suami istri dan anak. Dalam hal ini penyesuaian antara suami dan istri akan mempengaruhi penyesuaian diri anak, sikap dan kematangan emosi anak. 2). Hubungan orang tua dengan anak : Iklim emosional dalam keluarga sebagian besar tergantung pada orang tua. Stabilitas kepribadian anak sangat dipengaruhi oleh hubungan-hubungan diantara angggota keluarga. Disamping dipengaruhi oleh orang tua kepribadian anak menentukan iklim emosional dalam keluarga. Iklim emosional yang hangat, akrab, dan menerima merupakan iklim yang menguntungkan untuk perkembangan kepribadian anak. 3). Sikap penolakan orang tua : Sikap orang tua yang baik untuk perkembangan kepribadian anak adalah sikap mengerti, mencintai, dan menaruh perhatian pada anak. Sikap penolakan orang tua sangat berpengaruh terhadap perkembangan kepribadian anak. Sikap orang tua terhadap anak yang terlalu otoriter membuat anak merasa tidak diterima dalam lingkungan keluarga. 4). Figur

\footnotetext{
16 Agus Wibowo, Pendidikan Karakter Anak Usia Dini, Pustaka Belajar, 2013, hlm. 76.

${ }^{17}$ Riza Wahyu Aftasony, "Pola Asub Orang Tua dalam Membentuk Kemandirian Siswa Tunagrabita,hlm. 5.

${ }^{18}$ Riza Wahyu Aftasony, "Pola Asub Orang Tua dalam Membentuk Kemandirian Siswa Tunagrabita, hlm. 40.
} 
orang tua: Setiap anak dari mulai bayi hingga kelak dewasa sangat memerlukan figur dari orang tuanya. Figur yang baik dari keluarga akan menentukan pola perilaku anak yang baik pula. 5). Ketergantungan yang berlebihan terhadap orang tua : Ketergantungan yang berlebihan terhadap orang tua akan mempengaruhi penolakan orang tua terhadap anak, hal ini dikarenakan anak kurang bertanggung jawab, tidak mandiri dan akan terbawa sampai ke dewasa nanti.

\section{Pengasuhan orang tua yang bergaya melalaikan dan memanjakan}

Orang tua dengan gaya pengasuhan ini menurut Santrock tidak terlibat dengan kehidupan anak. Anak memiliki kebutuhan yang kuat untuk memperoleh perhatian dari orang tuanya. Anak yang dilalaikan oleh orang tuanya merasa bahwa hal-hal lain dalam kehidupan orang tuanya lebih penting dari dirinya sendiri. Anak yang orang tuanya lalai akan menjadikan anak tidak kompeten secara sosial, memiliki pengendalian diri yang buruk, dan tidak menyikapi kebebasan dengan baik. Pengasuhan orang tua yang lalai terjadi karena kurangnya pengawasan orang tua. ${ }^{19}$

Menurut Santrock orang tua dengan gaya pengasuhan ini sangat terlibat dalam kehidupan anaknya dan hanya memberikan sedikit tuntutan atau kendali terhadap anak. Orang tua dengan gaya pengasuhan memanjakan membiarkan anaknya melakukan apapun yang mereka inginkan. Akibatnya, anak tersebut tidak pernah belajar untuk mengendalikan perilakunya sendiri dan selalu berharap agar kemauannya diikuti orang tuanya.

Beberapa orang tua secara sengaja mengasuh anaknya melalui cara ini karena memiliki keyakinan yang keliru bahwa keterlibatan yang hangat dan sedikitnya pembatasan akan menghasilkan anak yang percaya diri dan kreatif. Muallifah menyatakan bahwa orang tua memberikan kebebasan kepada anak seluas mungkin. Anak tidak dituntut untuk belajar bertanggung jawab dan diberi hak yang sama dengan orang dewasa serta diberi kebebasan yang seluasluasnya untuk mengatur diri sendiri. Orang tua tidak banyak mengatur dan mengontrol anak, sehingga anak tidak diberi kesempatan untuk mandiri dan mengatur diri sendiri dan diberikan kewenangan untuk mengontrol dirinya sendiri. ${ }^{20}$

\section{Kemandirian Anak}

Menurut Sutari Imam Barnadib sebagaimana dikutip dalam Fatimah, kemandirian adalah meliputi kemampuan berinisiatif, kemampuan mengatasi masalah yang di hadapi, mempunyai rasa percaya diri dan dapat melakukan segala sesuatu sendiri tanpa bergantung pada orang lain. Pendapat tersebut juga diperkuat oleh Kartini dan Dali yang menyatakan bahwa kemandirian adalah keinginan untuk mengerjakan segala sesuatu bagi diri sendiri sehingga ia tidak bergantung pada orang lain. ${ }^{21}$

Menurut bacharuddin Musthafa kemandirian merupakan kemampuan untuk mengambil pilihan dan menerima konsekuensi yang menyertainya. Menurut Syamsu Yusuf kemandirian merupakan karakteristik dari kepribadian yang sehat (bealthy personality). ${ }^{22}$

Megan Northrup, dalam research Assistant dan di sunting oleh Stephen F. Duncan, guru besar dari School Of Family Life Birminghan Young University, menjelaskan sebagai berikut:

\footnotetext{
${ }^{19}$ Riza Wahyu Aftasony, "Pola Asub Orang Tua dalam Membentuk Kemandirian Siswa Tunagrabita”, (Skripsi S1 Fakultas Psikologi UIN Maulana Malik Ibrahim Malang 2015), hlm. 6.

${ }^{20}$ Riza Wahyu Aftasony, 'Pola Asub Orang Tua dalam Membentuk Kemandirian Siswa Tunagrahita,hlm. 6.

21 Janet key, Pendidikan anak usia dini, Yogyakarta, 2006, hlm. 40.

${ }^{22}$ Ahmad Susanto, Pendidikan Anak Usia Dini, Jakarta: Bumi Aksara, 2017, hlm.35.
} 
As chidren grow, they should be given more and more independence. At a young age chidren can select the clothes they wear, foot they eat, places to sit, and other small decisions. Older childrencan have more of a say in chosing appropriate time to be at home,when anf where to study, and which friends to associate with. The goal is to prepare children for the day they will leave their family and live without parental control.

Kemandirian yang di kemukakan oleh Northrup di atas diartikan sebagai kemampuan seorang anak untuk menentukan pilihan yang ia anggap benar. Dengan mengacu definisi tersebut, terdapat delapan unsur yang menyertai makna kemandirian bagi seorang anak, yaitu antara lain : Kemampuan untuk menentukan pilihan, Berani memutuskan atas pilihannya sendiri, Bertanggung jawab menerima konsekuensi yang menyertai pilihannya, Percaya diri, Mengarahkan diri, Mengembangkan diri, Menyesuaikan diri dengan lingkungannya, dan Berani mengambil resiko atas pilihannya. ${ }^{23}$

Dari berbagai pendapat di atas peneliti dapat menyimpulkan bahwa kemandirian adalah suatu keadaan seseorang dimana seseorang berusaha berdiri sendiri dalam arti tidak bergantung pada orang lain dalam keputusan dan mampu melaksanakan tugas hidup dengan penuh tanggung jawab.

\section{Metode Penelitian}

Jenis penelitian ini adalah penelitian kualitatif, yaitu penelitian yang berbentuk kata - kata, bukan dalam bentuk angka. Penelitian kualitatif diperoleh melalui berbagai macam teknik pengumpulan data misalnya wawancara, analisis dokumen, diskusi terfokus, atau observasi yang telah dituangkan dalam catatan lapangan ( transkip ). Bentuk lain penelitian kualitat Penelitian ini dilakukan di Lembaga SDN TAPELAN tepatnya berada di Desa Tapelan Kecamatan Kapas Kabupaten Bojonegoro.

Teknik pengumpulan data adalah suatu kegiatan untuk memperoleh data yang dibutuhkan dan dapat diolah menjadi suatu data yang dapat disajikan sesuai dengan masalah yang dihadapi. Data yang dikumpulkan dalam penelitian ini adalah data tentang pola asuh orang tua dan kemandirian anak. Data pola asuh orang tua dikumpulkan menggunakan teknik wawancara dan observasi, sedangkan data kemandirian anak menggunakan teknik observasi dan catatan lapangan.

\section{Hasil Dan Pembahasaan}

\section{Upaya Pola Asuh Demokratis di SDN Tapelan}

Untuk mengetahui Upaya pola asuh Demokratis dalam meningkatkan kemandirian anak usia dini di SDN TapelanTapelan tahun 2018, peneliti mengadakan observasi dan wawancara dengan orang tua anak. Berikut hasil observasi dan wawancara yang akan diteliti:

Berdasarkan hasil observasi pada tanggal 06 April 2018 bahwa penerapan pola asuh yang digunakan adalah pola asuh demokratis yaitu mendidik anak agar mandiri dengan cara membiasakan anak, memberikan arahan pada anak, memberikan kebebasan pada anak, selalu berkomunikasi pada anak. Hal itu sebagaimana yang dipaparkan oleh keluarga bapak sudarkim dan ibu winarseh dalam hasil wawancara peneliti sebagai berikut:

"Pola asuh yang saya gunakan yaitu memberikan arahan, memberikan

kebebasan pada anak, tetapi ada batasan-batasan yang harus diperhatikan". ${ }^{24}$

\footnotetext{
${ }^{23}$ Ahmad Susanto, Pendidikan Anak Usia Dini, Jakarta: Bumi Aksara, 2017, hlm.36.

${ }^{24}$ Hasil wawancara dengan ibu Winarseh, 09 April 2018.
} 
Hal yang sama dikemukakan oleh keluarga Bapak Prio Udiarto dan Ibu Eri Agustina bahwa:

"Pola Asuh yang saya gunakan berusaha tidak memanjakan anak, memberikan kebebasan pilihan pada anak, mengikuti keinginan anak, juga pengarahan dan penjelasan pada anak mana yang boleh dan mana yang tidak boleh". 25

Sejalan dengan hasil wawancara dengan keluarga bapak Udiarto dan Ibu Eri agustina, keluarga Bapak Salamun dan Ibu Muniroh juga mengungkapkan:

"Pola Asuh yang saya gunakan memberikan kebebasan pada anak dengan cara membiarkan anak bermain dengan teman-temannya sehingga anak mudah bergaul, dapat bersosialisasi dengan baik tidak mengekang anak dirumah terus-menerus. Ketika dirumah komunikasi dengan orang tua harus tetap ada", ${ }^{26}$

Hal ini juga diungkapkan oleh keluarga Bapak Amiri dan Ibu Siti Zulaikah bahwa:

"Pola asuh yang saya terapkan pada anak saya adalah selalu berusaha tidak memanjakan anak, memberikan arahan dan kebebasan tetapi ada batasan tegas seperti apabila dilarang ada penjelasannya "kenapa tidak boleh dan dilarang". 27

Berdasarkan hasil observasi dan wawancara tersebut dapat disimpulkan bahwa tujuan yang hendak dicapai dari pola asuh orang tua dalam meningkatkan kemandirian anak usia dini adalah adanya perubahan tingkah laku anak agar anak menjadi mandiri, tidak tergantung pada orang tua dan orang lain.

\section{Faktor-faktor Yang Mempengaruhi Pola Asuh Demokratis di SDN Tapelan}

Adapun faktor-faktor yang mempengaruhi penerapan pola asuh orang tua diantaranya : 1). Kepribadian orangtua : Meliputi bagaimana pengalaman orangtua sebelumnya ketika diasuh oleh orangtuanya, pengalaman- pengalaman dalam perkawinan. 2). Pendidikan orang tua : Apakah orangtua memiliki tingkat pendidikan yang tinggi atau tingkat pendidikan yang rendah, mempengaruhi mereka dalam mengasuh anak-anaknya. 3). Keadaan dalam keluarga : Meliputi besar kecilnya jumlah keluarga, variasi jenis kelamin, keadaan sosial ekonomi keluarga, faktor budaya dan lingkungan, faktor tempat tinggal dalam hal ini tinggal di desa atau di kota. 4). Pandangan orangtua terhadap anak dalam pelaksanaan pola asuh: Di dalam hal ini bagaimana orangtua menerapkan disiplin kepada anak, pemberian hadiah dan hukuman, bagaimana model penolakan dan penerimaan orangtua terhadap anak, bagaimana sikap orangtua terhadap anak yaitu konsisten atau tidak konsisten dan bagaimana harapan-harapan orangtua terhadap anak. 5). Karakteristik pribadi anak yang meliputi kepribadian anak, konsep diri, kondisi fisik (apakah cacat atau normal) dan kesehatan fisik.

Berdasarkan hasil observasi di atas, hasil wawancara dengan keluarga Bapak Sudarkim dan Ibu Sri Winarseh mengatakan:

"Faktor yang mempengaruhi pola asuh yaitu keluarga, karena keluarga sangat berpengaruh dan mempunyai peran penting dalam perkembangan anak selanjutnya." 28

\footnotetext{
${ }^{25}$ Hasil Wawancara dengan ibu Eri Agustina, 10 April 2018.

${ }^{26}$ Hasil wawancara dengan ibu Siti Muniroh, 11 April 2018.

${ }^{27}$ Hasil wawancara dengan ibu Siti Zulaikah, 12 April 2018.

${ }^{28}$ Hasil wawancara dengan ibu Sri Winarseh, 9 April 2018.
} 
Hal tersebut juga diungkapkan dari keluarga Prio Udiarto dan Ibu Eri Agustina bahwa:

"Faktor yang mempengaruhi pola asuh keaadan keluarga dan karakteristik anak, dimana dalam keluarga sudah mendukung disitu ada karakteristik anak yang berbeda. Anak saya memiliki karakter yang mudah terpengaruh oleh lingkungan sekitar". ${ }^{29}$

Hal ini sejalan dengan wawancara di atas keluarga Bapak Salamun dan Ibu Siti Muniroh juga menyampaikan hal yang sama:

"Pola asuh dapat dipengaruhi oleh kepribadian orangtua, yang meliputi pengalaman-pengalaman yang didapat orang tua selama ini, seperti halnya kegiatan parenting yang ada di lembaga". ${ }^{30}$

Hal serupa juga dikatatakan oleh keluarga Bapak Amiri dan Ibu Siti Zulaikah, sebagai berikut:

"Faktor yang mempengaruhi pola asuh adalah keluarga, pendidikan orang tua, karakteristik kepribadian anak. Alhamdulillah anak saya kalau sudah di beri penjelasan dia bisa menerima peraturan yang ditetapkan tapi disaat-saat tertentu dia juga sulit menerima, karena konsisten butuh kesabaran”.

Dari hasil observasi dan wawancara tersebut, peneliti dapat mengambil kesimpulan bahwa faktor yang mempengaruhi pola asuh adalah kepribadian orang tua dari hasil pengalamanpengalamannya, pendidikan orang tua, keadaan keluarga yang menjadi peran utama, pandangan orang tua terhadap anak dalam menerapkan pola asuh dan kepribadian anak.

\section{Upaya Kemandirian Anak Usia Dini di SDN Tapelan}

Kemandirian merupakan suatu sikap individu yang diperoleh secara kumulatif selama perkembangan, dimana individu akan terus belajar bersikap mandiri dalam menghadapi berbagai situasi lingkungan, sehingga individu pada akhirnya mampu berpikir dan bertindak sendiri. Kemandirian adalah meliputi kemampuan berinisiatif, kemampuan mengatasi masalah yang dihadapi, bertanggung jawab, disiplin, mempunyai rasa percaya diri dan dapat melakukan segala sesuatu sendiri tanpa bergantung pada orang lain.

Dalam hal ini berdasarkan hasil observasi, hasil wawancara dengan Bapak Sudarkim dan Ibu Sri Winarseh mengungkapkan:

"Saya dalam melatih kemandirian anak dengan memberikan kebiasaan pada anak makan sendiri, berani maju ke depan sendiri pada saat di sekolah." 31

Sejalan dengan hasil wawancara di atas keluarga Bapak Prio Udiarto dan Ibu Eri Agustina juga menyampaikan:

"Kemandirian itu sangat penting untuk dilatih sejak usia dini, saya melatih kemandirian pada anak saya dengan kebiasaan sehari-hari seperti makan sendiri, membawa tas sendiri waktu sekolah, sabar menunggu giliran,

\footnotetext{
${ }^{29}$ Hasil Wawancara dengan ibu Eri Agustina, 10 April 2018.

${ }^{30}$ Hasil Wawancara dengan Siti Muniroh, 11 April 2018.

31 Wawncara dengan ibu Sri Winarseh, 09 April 2018.
} 
memakai sepatu sendiri, ketika di rumah juga suka membantu saya membuat kue." 32

Hal yang sama diungkapkan oleh keluarga Bapak Salamun dan Ibu Siti Muniroh bahwa:

"Saya melatih kemandirian terhadap anak saya dengan memberi contoh dan kebiasaan setiap harinya seperti makan sendiri, minum sendiri, membereskan mainan, berbagi dengan teman- temannya, mencuci tangan sendiri." ${ }^{33}$

Hal serupa juga dikatatakan oleh keluarga Bapak Amiri dan Ibu Siti Zulaikah, sebagai berikut:

"Kalau saya untuk melatih kemandirian adalah yang terpenting contoh dan kebiasaan, karena anak usia dini masih suka meniru. Kebiasaan yang saya terapkan seperti membuang sampah sendiri, makan sendiri, membereskan mainan, memakai sepatu, berani maju sendiri, mau menyelesaikan tugas. Sebagai orang tua dalam melatih semua itu harus konsisten." ${ }^{34}$

Dari hasil observasi dan wawncara tersebut, peneliti dapat menyimpulkan bahwa kemandirian adalah kemampuan bertanggung jawab, disiplin, percaya diri, mampu mengatasi masalah tanpa bantuan orang lain.

Adapun tujuan yang hendak dicapai pada Upaya pola asuh Demokratis dalam meningkatkan kemandirian anak usia dini yaitu adanya perubahan pada diri anak untuk menjadi anak yang mandiri. Berdasarkan fakta temuan tersebut, menurut Rachmawati, pola asuh orang tua bertujuan untuk mengasuh dan menerapkan kemandirian kepada anaknya dalam membentuk watak, kepribadian dan memberikan nilai-nilai bagi anak agar dapat menyesuaikan diri dengan lingkungan. Orang tua menyadari bahwa kemandirian anak dibentuk dari lingkungan yang utama yaitu keluarga dan pola asuh orang tua yang akan mempengaruhinya. Dengan adanya pola asuh orang tua pada anak usia dini dapat membuat anak menjadi mandiri. ${ }^{35}$

Berdasarkan fakta temuan ini sesuai dengan indikator tingkat pencapaian perkembangan kemandirian anak usia dini dengan usia 2-4 tahun yang diantaranya. Hal ini diperkuat, menurut Listyandari ada beberapa cara orang tua memberikan bekal kemandirian untuk anak melalui kebiasaan sehari-hari : merapikan tempat tidur setiap bangun tidur, ajaklah anak menata tempat tidur. Untuk tahap awal, biarkan dia melihat dulu. Selanjutnya, meminta anak untuk membantu. Lama-kelamaan dia akan terbiasa dengan kegiatan ini, melibatkan anak di dapur, ajari anak mencuci gelas, piring dan peralatan makan lainnya, membersihkan lantai, menyapu lantai paling mudah dan aman dilakukan anak, merapikan meja belajar, merapikan diri setelah mandi dan biasakan anak menyisir sendiri rambutnya. ${ }^{36}$

Adapun cara orang tua dalam meningkatkan kemandirian pada anak melalui pembiasaan sikap, contoh dari orang tua serta melalui komunikasi antara anak dan orang tua. Pola asuh yang

\footnotetext{
32 Wawancara dengan ibu Eri Agustina, 10 April 2018.

33 Wawancara dengan ibu Siti Muniroh, 11 April 2018.

34 Wawancara dengan ibu Siti Zulaikah, 12 April 2018.

${ }^{35}$ Al Tridhonanto, Pola Asub Kreatif Panduan Untuk Orang Tua, (Jakarta : PT Elex Media Komputindo, 2013), hlm. 40.

${ }^{36} \mathrm{Al}$ Tridhonarto, Pola Asub Kreatif Panduan Orang Tua, hlm. 43.
} 
dilakukan orang tua berlangsung secara natural, tidak dibuat-buat dan terus-menerus, sehingga anak mampu memahami maksud dari keinginan orang tua melalui kebiasaan dan ajaran yang diberikan kepada anak.

Dalam meningkatkan kemandirian pada anak usia dini khususnya di SDN Tapelan terdapat beberapa faktor-faktor yang menjadi pendukung dan penghambat. Adapun faktor-faktor penghambat yang mempengaruhi kemandirian anak diantaranya lingkungan yang kurang mendukung, latar belakang yang berbeda-beda, orang tua yang tidak membiasakan anak untuk mandiri.

Faktor-faktor yang dapat memberikan pengaruh terhadap kemandirian anak, yaitu bantuan yang berlebihan, banyak orang tua yang kasihan melihat anaknya bersusah payah melakukan sesuatu sehingga langsung memberikan pertolongan perlakuan yang menganggap anak tidak bisa apa-apa, seperti itu sebenarnya memberi kesempatan pada anak untuk memanipulasi bantuan orang tua, anak cenderung tidak mau berusaha dikala mengalami kesulitan, rasa bersalah orang tua dalam hal ini sering dialami oleh orang tua yang keduanya bekerja, sehingga orang tua ingin menutupi rasa bersalah mereka dengan memenuhi segala keinginan anak dan terlalu melindungi anak.

Pola asuh yang diberikan orang tua sangat membantu dalam kemandirian anak, terutama kemandirian tingkah laku. Bahwa kemandirian anak akan tercapai apabila orang tua melakukan upaya melalui berbagai kegiatan yang menunjang kemandirian anak. Orang tua harus melatih kemandirian anak sejak dini agar anak tidak tergantung pada orang lain.

\section{KESIMPULAN}

Berdasarkan pembahasan pada bab-bab sebelumnya dan hasil wawancara telah didapatkan kesimpulan dari skripsi yang berjudul "Upaya Meningkatkan Kemandirian Anak Usia Dini melalui Pola asuh Demokratis Di Desa Tapelan”. Peneliti dapat menarik kesimpulan:

Bahwa dengan cara pola asuh Demokratis memberikan kebebasan pada anak, mendengarkan keinginan anak, juga mengarahkan dan memberi penjelasan pada anak, komunikasi yang baik, dan adanya keterbukaan antara anak dengan orang tua. Faktor-fakor yang mempengaruhi pola asuh demokratis yaitu kadaan keluarga, kepribadian orang tua, pendidikan orang tua, karakteristik pribadi anak.

Upaya kemandirian dengan cara pola asuh Demokratis membiasakan anak untuk makan sendiri, dengan cara pola asuh demokratis menyuruh anak makan dengan sabar. Pola asuh Demokratis memberikan contoh dan menyuruh anak untuk memakai baju sendiri dengan cara pola asuh demokratis. Pola asuh demokratis cara orang tua memberikan motivasi atau dorongan kepada anak bahwa anak mampu mengerjakan sesuatu dengan mandiri dengan cara pola asuh demokratis.

\section{DAFTAR PUSTAKA}

Arikunto, Suharsimi. 1992. Prosedur Penelitian (Suatu Pendekatan Praktik). Jakarta: PT Rineka Cipta.

Arikunto, Suharsimi. 2010. Prosedur Penelitian. Jakarta: Rineka Cipta. Azwar, Saefudin. 2000. Metodelogi Penelitian. Yogyakarta: Pustaka Pelajar. Azwar, Saiffudin. 2010. Metode Penelitian. Yogyakarta: Pustaka Pelajar.

Basri, Hasan. 2000. Remaja Berkualitas. (problematika remaja dan solusinya) Yogyakarta: Pustaka Jaya. 
Gunarsa, Singgih D. 1995. Psikologi Perkembangan Anak Dan Remaja. Jakarta: PT BPK Gunung Mulia.

Hadi, Sutrisno. 2004. Metodelogi Research (Jilid 2). Yogyakarta: PT Andi. Hasan, Maimunah. 2009. Pendidikan anak usia dini. Jogjakarta: Diva Press.

Ilahi, Mohammad Takdir. 2013. Quantum Parenting Kiat Sukses Mengasuh Anak Secara Efektif dan Cerdas. Jogjakarta: Kata hati.

Jihad, Asep \& Haris, Abdul. 2008. Evaluasi Pembelajaran. Bandung: Multi Presindo.

M.Pd, Agus Wibowo. 2013. Pendidikan Karakter Anak Usia Dini. Yogyakarta : Pustaka Belajar.

Nugraha, Ali. Zaman, Badru. A. Sy Dina, Dwiyana. 2015. Program Pelibatan Orang Tua Dan Masyarakat. Tangerang Selatan : Universitas Terbuka.

Rahman, M. Fauzi. 2011. Islamic Parenting. Jakarta: Erlangga.

Santrock, John.W. 2002. Life-Span Development Perkembangan Masa Hidup.Edisi Ke Lima. Jakarta: Erlangga.

Siregar, Sofyan. 2010. Statistika Diskriptif. Jakarta: PT RajaGrafindo Persada. Sugiyono. 2009. Metode Penelitian Kualitatif dan R \& D. Bandung: Alfabeta. Sutrisno, Hadi. 2008. Metodelogi Research. Yogyakarta: Andi Offset.

Syamsudin. 2007. Metode Penelitian Pendidikan Bahasa. Bandung: PT Remaja Rosdakarya.

Ulya, Laila Listiana. 2013. Hubungan Antara Pola Asuh Demokratis Dengan Kemandirian Dalam Pengambilan Keputusan. 2013. Universitas Muhammadiyah Surakarta.

Winarsih. 2010. "Hubungan Pola Asuh Dengan Kemandirian Belajar". Skripsi. Surakarta : UMS Tidak Diterbitkan.

Wulandari, Dyah. 2011. "Hubungan Pola Asuh Orang Tua Dengan Perilaku Sosial Anak”. Skripsi. Surakarta : UMS 